Optimasi Proses Pembuatan Sohun dari Pati Ubi Banggai - Kusnandar, dkk Jurnal Pangan dan Agroindustri Vol.8 No.3: 163-174, Juli 2020

\title{
OPTIMASI PROSES PEMBUATAN SOHUN DARI PATI UBI BANGGAI (Dioscorea alata)
}

\section{Optimization of Starch Noodle Processing from Banggai Yam (Dioscorea alata) Starches}

\author{
Feri Kusnandar, Mimah Mutmainah, Tjahja Muhandri
}

\author{
Departemen Ilmu dan Teknologi Pangan, Fakultas Teknologi Pertanian, \\ Institut Pertanian Bogor (Bogor University). Kampus IPB Dramaga, Bogor 16680 \\ *Penulis Korespondensi, Email: fkusnandar@apps.ipb.ac.id
}

\begin{abstract}
ABSTRAK
Ubi Banggai mengandung pati dengan amilosa tinggi yang dapat diolah menjadi sohun. Penelitian ini bertujuan untuk mengoptimasi pengolahan sohun pati ubi Banggai dari varietas Baku Pusus, Baku Tuu Oloyo dan Baku Boan. Sohun dibuat dengan mencampurkan pati dengan air, dilewatkan dalam ekstruder dan dikeringkan. Sepuluh kombinasi jumlah air (50-65\% dari berat pati) dan suhu barrel $\left(95-100^{\circ} \mathrm{C}\right)$ dirancang dengan response surface methodology. Optimasi proses menggunakan pati varietas Baku Pusus, dan kondisi terpilih diterapkan pada dua varietas lainnya. Kehilangan padatan akibat pemasakan (KPAP), daya serap air (DSA) dan elongasi dianalisis. Sohun pati Baku Pusus dengan kombinasi air $(61 \%)$ dan suhu barrel $\left(99^{\circ} \mathrm{C}\right)$ memiliki KPAP yang rendah (6.16\%), dan DSA dan elongasi tinggi (278.08\% dan 236.95\%). Sohun Baku Tuu Oloyo dan Baku Boan yang diproses pada kondisi yang sama juga menghasilkan KPAP $<10 \%$, serta \%DSA dan \%elongasi yang tidak berbeda dari Baku Pusus. Sohun Baku Boan berwarna paling keabu-abuan dibanding sohun lainnya.
\end{abstract}

Kata kunci: Elongasi, Response surface methodology, Sohun, Ubi banggai

\section{ABSTRACT}

Banggai yam contains starch with a high amylose content, which is potentially processed into starch noodle. This study aimed at optimizing starch noodle processing from Banggai yam starches (Baku Pusus, Baku Tuu Oloyo and Baku Boan). Starch noodle was processed by mixing starch with water, extruded and dried. Ten experimental combinations of water (50-65\% of starch weight) and barrel temperature $\left(95-100^{\circ} \mathrm{C}\right)$ applying an RSM. Process optimization used Baku Pusus yam, and a selected condition was applied for two others. Cooking loss (CL), water absorption capacity (WAC) and elongation was analyzed. Starch noodle made of Baku Pusus starch in combination of $61 \%$ water and $95^{\circ} \mathrm{C}$ barrel showed a low CL (6.16\%), high WAC (278.08\%) and elongation (236.95\%). Starch noodle from Baku Tuu Oloyo and Baku Boan processed at the same condition showed $C L<10 \%$, and had \%WAC and \%elongation similar to Baku Pusus. Starch noodle of Baku Boan had the most grayish color.

Keywords: Banggai yam, Elongation, Response surface methodology, Starch noodle

\section{PENDAHULUAN}

Ubi Banggai merupakan ubi lokal yang banyak dibudidayakan di Banggai Kepulauan, Sulawesi Tengah. Masyarakat setempat mengonsumsinya sebagai makanan pokok atau mengolahnya menjadi kolak, keripik, dan kue (Purnomo, 2010). Ubi Banggai termasuk famili Dioscoreaceae genus Dioscorea dengan varietas yang banyak (Mulch et al., 2015). Boy dan Soeharsono (2013) mengidentifikasi 44 varietas ubi Banggai yang masing-masing memiliki ciri khas dan diberi nama lokal, di antaranya varietas Baku Pusus, Baku Tuu Oloyo dan Baku Boan. Ubi Baku Pusus berbentuk lonjong, warna kulit coklat, permukaan kasar dan tebal, dan warna 
dagingnya putih. Ubi Baku Tuu Oloyo juga berbentuk lonjong, namun kulitnya halus dan tipis, dan warna daging kekuningan, sedangkan ubi Baku Boan berbentuk bulat, warna kulit coklat muda, dan warna daging putih keunguan (Mutmainah, 2020).

Ubi Banggai mengandung karbohidrat yang tinggi $(73.04-74.87 \%$ bb), dan sebagian besar adalah pati (Amar, 2020). Mutmainah (2020) melaporkan bahwa ekstrak pati ubi Banggai mengandung rata-rata pati $88.5 \%$ bk dengan kadar amilosa $60.29-62.88 \%$ bk dari total pati. Kandungan amilosa yang tinggi ini merupakan kekhasan dari ubi Banggai yang membedakannya dari umbi-umbian lainnya. Sebagai perbandingan, ubi jalar mengandung karbohidrat 85.92\%bk dengan kadar amilosa 30.30\%bk (Retnaningtyas dan Putri, 2014), sedangkan pati singkong $84.5 \%$ bk dengan kadar amilosa 19.5\%bk (Oladunmoye et al., 2015).

Nadia et al. (2014) melaporkan profil pasting dari beberapa varietas Dioscorea yang menunjukkan suhu awal pasting yang tinggi $\left(82.5-83.7^{\circ} \mathrm{C}\right)$, viskositas puncak yang tinggi, viskositas breakdown yang rendah dan viskositas setback yang tinggi. Profil pasting ini mirip profil pati kacang hijau ( $\mathrm{Li}$ et al., 2011), pati yang dimodifikasi dengan ikatan silang (Xiao et al., 2012) atau pati yang dimodifikasi dengan heat moisture treatment (HMT) (Purwani et al., 2006). Dengan kandungan amilosa yang tinggi dan profil pasting tersebut, maka pati ubi Banggai berpotensi untuk diaplikasikan sebagai bahan baku pembuatan sohun (Akinoso et al., 2016).

Sohun merupakan kelompok produk pasta yang memiliki penampakan transluen (bening) dan tidak mudah patah saat kering, serta memiliki tekstur yang cukup elastis, tidak lengket, tidak mudah putus dan padatannya sedikit larut dalam air ketika dimasak (Wang et al., 2015). Struktur granula yang kompak dan amilosa yang tinggi berperan dalam pembentukan tekstur sohun yang kokoh selama ekstrusi panas dan membentuk gel yang kuat setelah pendinginan (Tam et al., 2004; Zhong et al., 2018). Pati kacang hijau merupakan bahan ideal dalam pembuatan sohun, karena karakteristiknya memenuhi kebutuhan proses dan menghasilkan sohun yang transluen, elastis, padatannya sedikit larut dalam air selama pemasakan, serta daya serap air dan elongasinya yang tinggi (Collado et al., 2001; Wang et al., 2015).

Proses pembuatan sohun mencakup tahapan pencampuran pati dan air hingga membentuk pasta, kemudian diekstrusi dan untaian mi yang terbentuk dilewatkan ke dalam air panas sehingga mengalami gelatinisasi secara sempurna, kemudian didinginkan, dipisahkan dan dikeringkan (Wang et al., 2015). Proses pembekuan kadang-kadang dilakukan untuk membentuk untaian mi yang mudah dipisahkan setelah pengeringan dan membentuk penampakan transluen (Muhammad et al., 1999).

Penambahan air dan suhu barrel saat ekstrusi merupakan tahapan penting dalam proses pembuatan sohun dan kondisinya dapat berbeda untuk bahan yang berbeda (Muhandri dan Subarna, 2009). Jumlah air yang terlalu sedikit menghasilkan pasta pati yang mudah hancur, sedangkan bila penambahan air terlalu banyak akan menghasilkan pasta pati yang terlalu basah dan lengket yang sulit ditangani selama proses ekstrusi. Proses gelatinisasi pasta pati terjadi di dalam ekstruder yang suhu barrel-nya diatur di atas suhu awal pasting dari pati. Suhu barrel yang terlalu rendah menyebabkan sebagian pati belum tergelatinisasi sempurna, sedangkan suhu barrel yang terlalu tinggi dapat menyebabkan terjadinya gelatinisasi pati yang berlebihan.

Kadar amilosa yang ideal untuk bahan baku sohun berkisar $32-35 \%$ yang dimiliki oleh pati kacang hijau (Li et al., 2011). Menurut Tam et al. (2004), sohun dapat diolah dari sumber pati lain dengan kadar amilosa $27-28 \%$ dan menggunakan teknologi proses yang sama untuk sohun kacang hijau, yaitu dengan melewatkan adonan pada die tanpa tekanan atau mesin ekstrusi bertekanan. Pati ubi yang memiliki kadar amilosa lebih dari 35\% masih dapat diproses menjadi untaian sohun apabila dibantu dengan proses ekstrusi bertekanan. Pati dari sumber lain dilaporkan untuk pembuatan sohun atau bihun, diantaranya pati jagung (Interpares et al., 2015), pati ubi jalar (Chen et al., 2002), tepung gembili dan sagu (Romadhoni dan Harijono, 2015), pati singkong yang dimodifikasi ikatan silang (Muhammad et al., 1999), dan pati sagu yang dimodifikasi HMT (Herawati et al., 2010; Lase et al., 2013; Tsakama et al., 2013). Umumnya sohun, khususnya yang dibuat dari pati alami, memiliki mutu yang lebih rendah 
dibandingkan sohun pati kacang hijau, yaitu memiliki KPAP yang tinggi, lengket dan elongasinya rendah ketika dimasak. Hal ini disebabkan oleh kandungan amilosanya yang rendah serta pasta patinya yang kurang tahan oleh proses pemanasan (Chen et al., 2002).

Penelitian ini bertujuan untuk mengoptimasi proses pembuatan sohun pati ubi Banggai dengan menggunakan pati Baku Pusus sebagai model. Kondisi proses yang dioptimasi adalah persen penambahan air dan suhu barrel selama proses ekstrusi dengan menggunakan response surface methodology (RSM). Respon yang diukur adalah kehilangan padatan akibat pemasakan, daya serap air dan elongasi. Hasil optimasi proses diaplikasikan pada pati dua varietas ubi Banggai lainnya (Baku Tuu Oloyo dan Baku Boan), dan karakteristik sohun yang dihasilkan kemudian dibandingkan dari sohun pati Baku Pusus.

\title{
BAHAN DAN METODE
}

\section{Bahan}

Ubi Banggai (Baku Pusus, Baku Tuu Oloyo dan Baku Boan) diperoleh dari Desa Gansal, Kecamatan Tinangkung Selatan, Kabupaten Banggai Kepulauan. Ubi Banggai yang digunakan adalah yang memiliki umur panen delapan bulan pada musim tanam bulan September 2018 dan diperoleh dari lokasi tanam dan petani yang sama.

\begin{abstract}
Alat
Peralatan yang digunakan terdiri dari peralatan untuk ekstraksi pati ubi Banggai, pembuatan sohun, dan analisis. Ekstraksi pati ubi banggai menggunakan rasper, pulper, blender kering, ayakan 100 mesh dan tray dryer. Proses pembuatan sohun menggunakan hand mixer, ekstruder pemasak-pencetak ulir tunggal (forming-cooking extruder model Scientific Laboratory Single Screw Extruder type LE 25-30/C), dan tray dryer. Peralatan analisis di antaranya Texture Analyzer Stable Micro-System (TA-XT2i dan Chromamometer (CR-A33D, Konica Minolia).
\end{abstract}

\section{Tahapan penelitian}

Penelitian mencakup tahapan ekstraksi pati dari tiga varietas ubi Banggai, optimasi proses pembuatan sohun menggunakan pati dari Baku Pusus sebagai model, dan perbandingan mutu fisik sohun dari tiga pati ubi Banggai (Baku Pusus, Baku Tuu Oloyo dan Baku Boan) yang diproses pada kondisi optimum.

\section{Ekstraksi pati}

Proses ekstraksi pati mengacu pada metode Nadia et al. (2014) dengan modifikasi. Ubi dikupas, dibersihkan, dipotong-potong dan direndam dalam larutan $\mathrm{NaCl}$ 15\% selama 60 menit untuk menghilangkan lendir. Ubi yang telah dikupas kemudian dicuci dengan air sampai bersih dan kembali ditampung dalam wadah berisi air bersih. Ubi diparut dengan menggunakan rasper, lalu slurry yang diperoleh ditimbang dan ditambah larutan natrium metabisulfit $0.1 \%$ dengan perbandingan 1:4 yang bertujuan untuk mencegah reaksi pencokelatan. Slurry disaring dengan menggunakan kain saring, dan diperas. Suspensi yang diperoleh ditampung dalam wadah dan diendapkan selama 6 jam sampai terbentuk endapan pati berwarna putih.Filtrat dibuang, dan endapan dicuci dengan air (rasio: 1:2), lalu diendapkan kembali selama 13 jam. Filtrat dibuang dan endapan dicuci kembali seperti sebelumnya. Endapan pati dipindahkan ke dalam loyang besar dan dikeringkan dalam cabinet dryer $50^{\circ} \mathrm{C}$ selama 3 jam. Pati ubi Banggai dihaluskan dengan menggunakan blender kering dan diayak dengan ayakan 100 mesh.

\section{Optimasi proses pembuatan sohun}

Pembuatan sohun ubi Banggai mengacu Muhandri et al. (2017). Proses diawali dengan mencampurkan pati Baku Pusus dengan air (50-65\% dari total pati) dan larutan $\mathrm{NaCl} 2 \%$, kemudian diaduk dengan mixer selama 3 menit untuk memperoleh adonan basah (pasta). 
Penambahan larutan $\mathrm{NaCl}$ bertujuan agar pasta lebih kompak, sehingga tekstur sohun lebih kokoh dan elastis (Muhandri dan Subarna, 2009). Adonan dilewatkan pada ekstruder pemasakpencetak ulir tunggal dengan diameter die $1 \mathrm{~mm}$, kecepatan screw $130 \mathrm{rpm}$, dan suhu barrel $95-100^{\circ} \mathrm{C}$. Untaian sohun basah kemudian ditiriskan dan dikeringkan. Kombinasi persen penambahan air dan suhu barrel pada rentang yang dipilih dirancang oleh software Design Expert 10 (DX10) (Muhandri et al., 2017). Sepuluh kombinasi perlakuan yang diperoleh disajikan pada Tabel 1. Sohun diproses dan respon kemudian diukur (KPAP, daya serap air dan elongasi). Data diolah dengan menggunakan software DX10 sehingga diperoleh model persamaan prediksi untuk masing-masing respon, dan dapat ditentukan satu kombinasi proses yang optimum. Verifikasi dilakukan dengan menyiapkan kembali sohun pada kombinasi optimum yang terpilih, dan respon dari hasil prediksi persamaan model dan nilai aktual dari hasil analisis dibandingkan.

\section{Perbandingan karakteristik sohun tiga varietas ubi Banggai}

Kondisi optimum yang diperoleh kemudian diaplikasikan pada pembuatan sohun dari dua pati varietas lainnya (Baku Tuu Oloyo dan Baku Boan). Ketiga sohun yang diperoleh kemudian dianalisis warna (sohun kering dan setelah dimasak), KPAP, daya serap air dan elongasi.

\section{Metode}

Data respon dari tahap optimasi (KPAP, daya serap air, dan elongasi) dianalisis ragam dan dibuat model persamaannya dengan software DX10. Ketepatan model untuk memprediksi kondisi optimum berdasarkan pada nilai $\mathrm{p}<0.05$, Lack of Fit (LoF), Pred $R$-Squared $\left(\mathrm{R}^{2}\right)$, dan Adeq Precision. Validitas model dievaluasi berdasarkan hasil verifikasi, yaitu dari kedekatan antara nilai yang diprediksi dari model matematika dengan nilai aktual berdasarkan kriteria Confident Interval (Cl) dan Prediction Interval (Cl) (Prabudi et al., 2018). Data parameter mutu dari sohun ketiga varietas ubi Banggai dinyatakan dalam bentuk nilai rata-rata \pm standar deviasi, dan uji beda dilakukan dengan menggunakan Program Minitab 16.

\section{Prosedur analisis}

\section{Analisis kehilangan padatan akibat pemasakan (Muhandri et al., 2017)}

Sebanyak $2 \mathrm{~g}$ sampel (dalam basis kering, Ak) direbus dalam air $200 \mathrm{~mL}$ selama 6 menit, kemudian ditiriskan dan dibilas dengan air destilasi. Sampel dipindahkan ke dalam cawan yang telah diketahui beratnya, lalu dikeringkan dalam oven $105^{\circ} \mathrm{C}$ selama 6 jam. Sampel ditimbang sehingga diperoleh berat kering (C). KPAP dihitung sebagai persen berat padatan (Ak-C) terhadap berat sampel (Ak).

\section{Daya serap air (Tsakama et al., 2013)}

Sebanyak $2 \mathrm{~g}$ sampel (A) direbus dalam air $200 \mathrm{~mL}$ selama 6 menit. Setelah ditiriskan, sampel dipindahkan ke dalam cawan yang telah diketahui beratnya lalu ditimbang (B). Daya serap air (DSA) dihitung sebagai persen berat air yang diserap (B-A) terhadap berat sampel (A).

\section{Elongasi (Muhandri et al., 2017) dengan modifikasi}

Persen elongasi sohun dianalisis dengan menggunakan TA-XT2i. Sampel (5 g) direbus dalam air $200 \mathrm{~mL}$ selama 6 menit. Setelah ditiriskan dan didinginkan, elongasi diukur dengan melilitkan untaian sampel pada dua probe yang diatur jaraknya sejauh $2 \mathrm{~cm}$, kemudian ditarik dengan kecepatan $0.3 \mathrm{~cm} /$ detik. Pengukuran dilakukan sebanyak tiga kali untuk setiap sampel. Persen elongasi dihitung sebagai berikut:

$$
\text { Elongasi }(\%)=1-\left(\frac{\text { Waktu putus sampel }(s) \times 0.3 \frac{\mathrm{cm}}{\mathrm{s}}}{2 \mathrm{~cm}}\right) \times 100
$$




\section{Analisis warna}

Warna sampel sohun kering dan yang telah dimasak dianalisis dengan menggunakan Lab colorimeter. Sampel sohun kering dipotong-potong kecil, kemudian diletakkan secara merata di atas cawan petri, lalu diukur parameter warnanya (nilai L, a dan b). Untuk sohun matang, sampel $(5 \mathrm{~g})$ direbus dalam air $200 \mathrm{~mL}$ selama 6 menit, dibilas dengan air mengalir, ditiriskan dan pindahkan dalam cawan alumunium sampai penuh, lalu diukur warnanya.

\section{HASIL DAN PEMBAHASAN}

\section{Optimasi proses}

Tabel 1 memberikan sepuluh kombinasi perlakuan (persen air dan suhu barrel) dan masing-masing responnya. KPAP merupakan parameter penting yang menunjukkan kualitas sohun yang dihasilkan, yaitu seberapa banyak padatan yang masuk ke dalam fase air ketika dilakukan proses pemasakan. Persen KPAP sohun Baku Pusus berkisar antara 7.66\%-19.57\%, yaitu yang tertinggi dihasilkan dari kombinasi penambahan air $60 \%$ dan suhu barrel $90^{\circ} \mathrm{C}$, dan yang terendah pada kombinasi persen penambahan air $55 \%$ dan suhu barrel $100^{\circ} \mathrm{C}$. Persen KPAP yang diinginkan adalah di bawah $10 \%$ yang memenuhi standar sohun dari The Chinese Trade Standards (Wang et al., 2015; Collado et al., 2001). Dengan demikian, tidak seluruh kombinasi perlakuan menghasilkan sohun yang memenuhi syarat KPAP (Tabel 1). Penggunaan suhu ektruder yang terlalu rendah dapat menghasilkan struktur sohun yang kurang kompak dan mudah putus saat ditarik serta mudah hancur saat dimasak. Pada suhu barrel $90^{\circ} \mathrm{C}$, sebagian pati diduga belum tergelatinisasi yang dapat menurunkan kemampuan pasta pati membentuk gel serta proses retrograsi sehingga sohun yang dihasilkan tidak kokoh (Muhandri dan Subarna, 2009). Menurut Srichuwong (2006) semakin tinggi tingkat gelatinisasi pati, maka semakin banyak amilosa yang keluar dari granula sehingga meningkatkan viskositas dan membentuk jaringan kuat ketika retrogradasi.

Tabel 1. Persen KPAP, daya serap air dan elongasi sohun pati Banggai sebagai respon perlakuan persen penambahan air dan suhu barrel

\begin{tabular}{|c|c|c|c|c|c|}
\hline \multirow{2}{*}{ Run } & \multicolumn{2}{|c|}{ Perlakuan } & \multicolumn{3}{|c|}{ Respon } \\
\hline & $\mathbf{X}$ & $\mathbf{Y}$ & KPAP (\%) & DSA (\%) & Elongasi (\%) \\
\hline 1 & 50 & 100 & 9.71 & 321.63 & 200.75 \\
\hline 2 & 55 & 100 & 7.03 & 419.61 & 168.63 \\
\hline 3 & 60 & 100 & 6.07 & 485.51 & 201.78 \\
\hline 4 & 55 & 95 & 9.80 & 557.46 & 203.28 \\
\hline 5 & 55 & 95 & 8.90 & 459.42 & 262.00 \\
\hline 6 & 60 & 95 & 10.45 & 439.96 & 195.25 \\
\hline 7 & 65 & 95 & 8.15 & 374.20 & 216.83 \\
\hline 8 & 65 & 95 & 7.66 & 370.52 & 207.80 \\
\hline 9 & 60 & 90 & 18.57 & 477.67 & 101.50 \\
\hline 10 & 60 & 90 & 18.07 & 492.96 & 86.30 \\
\hline
\end{tabular}

$\mathrm{X}=$ Persen penambahan air, $\mathrm{Y}=$ suhu barrel $\left({ }^{\circ} \mathrm{C}\right)$

Daya serap air (DSA) menunjukkan kemampuan penyerapan air selama proses pemasakan. Persen DSA berkisar 321.63-557.51\% (Tabel 1), yaitu yang terendah dihasilkan dari kombinasi penambahan air $50 \%$ dan suhu barre/ $100^{\circ} \mathrm{C}$, dan yang tertinggi pada $55 \%$ penambahan air dan suhu barre $195^{\circ} \mathrm{C}$. Persen DSA yang diinginkan adalah yang tidak terlalu rendah atau terlalu tinggi. Persen DSA yang terlalu rendah menunjukkan sohun kurang dapat menyerap air yang menghasilkan tekstur sohun yang keras. Persen DSA yang terlalu tinggi menghasilkan sohun masak yang terlalu mengembang dan teksturnya mudah hancur.

Persen elongasi menunjukkan pertambahan panjang sohun hingga putus akibat gaya tarikan. Sohun dengan nilai elongasi yang tinggi menunjukkan untaian sohun yang tidak mudah 
putus. Persen elongasi sohun ubi Baku Pusus berkisar $86.30-262.00 \%$, yaitu yang terendah dihasilkan dari kombinasi $60 \%$ air dan suhu barrel $90^{\circ} \mathrm{C}$, dan yang tertinggi pada kombinasi $55 \%$ air dan suhu barrel $95^{\circ} \mathrm{C}$ (Tabel 1). Muhandri (2011) menyatakan peningkatan suhu ekstruder dapat meningkatkan derajat gelatinisasi pati sehingga terbentuk struktur gel yang kuat dan elongasi sohun menjadi tinggi.

Hasil analisis ragam menunjukkan perlakuan penambahan air dan suhu barrel berpengaruh secara signifikan $(p<0.05)$ terhadap persen KPAP, DSA dan elongasi (Tabel 2). Hal ini menunjukkan pemilihan respon untuk proses optimasi telah sesuai. Perlakuan percobaan dinyatakan berpengaruh secara signifikan terhadap respon apabila memiliki nilai $\mathrm{p}<0.05$ (Hendrawati et al., 2016; Ratnawati et al., 2012). Kriteria Lack of Fit (LoF) yang diharapkan adalah apabila nilai $p>0.05$ yang menunjukkan rentang perlakuan telah sesuai. Parameter DSA dan elongasi memiliki nilai LoF dengan $p>0.05$, sedangkan KPAP memiliki nilai $\mathrm{p}<0.05$. Namun demikian, parameter KPAP masih dapat digunakan karena memiliki persamaan model dengan nilai $\mathrm{p}<0.05$ (Ratnawati et al., 2012). Nilai $A d j R^{2}$ dan Pred $R^{2}$ setiap respon memenuhi kriteria yang diinginkan, yaitu mendekati angka 1.0 (Hendrawan et al., 2016). Nilai Adeq Pred diharapkan lebih dari 4.0 dan setiap respon memenuhi kriteria tersebut. Tingginya nilai Adeq Pred menunjukkan bahwa model prediksi memiliki presisi yang tinggi (Bas dan Boyaci, 2007). Dengan demikian, persamaan model dari parameter KPAP, DSA dan elongasi dikembangkan. Persamaan model untuk KPAP dan elongasi adalah kuadratik, sedangkan DSA adalah model 2F1 (Tabel 2).

Tabel 2. Signifikansi perlakuan persen penambahan air dan suhu barre/ terhadap respon

\begin{tabular}{|c|c|c|c|c|c|c|c|}
\hline \multirow{2}{*}{ Respon } & \multirow[b]{2}{*}{ Model } & \multicolumn{2}{|c|}{ Nila P } & \multirow{2}{*}{$\mathbf{R}^{2}$} & \multirow{2}{*}{ Adj $R^{2}$} & \multirow{2}{*}{ Pred $\mathbf{R}^{2}$} & \multirow{2}{*}{$\begin{array}{c}\text { Adeq } \\
\text { Prescision }\end{array}$} \\
\hline & & Model & Lack of Fit & & & & \\
\hline & $\mathrm{K}$ & 0.0016 & $0 .(1$ & 0 & & & 18.197 \\
\hline DS & $2 \mathrm{~F}$ & 0.01 & 0.5325 & 0.7 & & 98 & 7.671 \\
\hline Elongasi & Kuadratik & 0.0225 & 0.9046 & 0.9256 & 0.8326 & 0.716 & 8.267 \\
\hline
\end{tabular}

Tabel 3 menyajikan model matematika untuk parameter persen KPAP, DSA dan elongasi. Berdasarkan persamaan tersebut, maka terlihat bahwa persen penambahan air (X) dan suhu barrel $(\mathrm{Y})$, baik secara individu, kombinasi dan kuadratik berpengaruh secara signifikan terhadap persen KPAP dan elongasi. Untuk persen DSA, $X$ (persen air) dan $Y$ (suhu barrel) berpengaruh secara signifikan secara individu atau kombinasinya. Model persamaan KPAP dan elongasi memiliki nilai $R^{2}$ yang tinggi $(>0.90)$ yang menunjukkan validitas model yang baik sebagai prediktor, sedangkan persen DSA memiliki nilai $R^{2}$ yang agak rendah namun masih cukup valid untuk digunakan sebagai prediktor karena memiliki nilai $p<0.05$. Berdasarkan model persamaan pada Tabel 3, maka dapat disimpulkan bahwa penambahan air, suhu barrel, dan interaksi antara air dan suhu barrel berpengaruh terhadap KPAP, DSA dan elongasi. Gambar 1, 2 dan 3 secara berturut-turut menyajikan model tiga dimensi pengaruh persen air dan suhu barrel terhadap persen KPAP, DSA dan elongasi.

Penentuan kondisi proses optimum dilakukan dengan menetapkan target dari setiap respon (Tabel 4). Respon KPAP merupakan parameter yang utama sehingga pada penelitian ini ditentukan tingkat impotance +++++ dengan nilai yang ditargetkan minimize karena formula yang diinginkan dapat menghasilkan nilai KPAP rendah. Respon DSA tujuan penetapannya adalah in range dengan tingkat impotance +++, karena tidak terdapat nilai standar yang harus dipenuhi sehingga tidak ditetapkan secara spesifik. Respon elongasi ditentukan dengan tingkat impotance +++ dan ditargetkan memiliki nilai $213 \%$ yang mengacu pada nilai elongasi sohun ubi jalar komersil. Berdasarkan proses optimasi tersebut, maka diperoleh kondisi perlakuan yang optimum, yaitu $61 \%$ penambahan air dan suhu barrel $99^{\circ} \mathrm{C}$ (Tabel 4). Kombinasi perlakuan tersebut menghasilkan prediksi persen KPAP (6.0\%), DSA (459.0\%) dan elongasi (213.0\%). 
Tabel 3. Konstanta model persamaan memprediksi nilai respon sohun pati ubi Banggai

\begin{tabular}{crrr}
\hline Konstanta & KPAP (\%) & DSA (\%) & Elongasi (\%) \\
\hline $\mathrm{a}$ & 421.0632 & 30453.5015 & 2962.8395 \\
$\mathrm{X}$ & 11.5055 & -498.4349 & -410.7066 \\
$\mathrm{Y}$ & -14.5666 & 307.14520 & 191.6812 \\
$\mathrm{XY}$ & -0.0922 & 5.1034 & 2.8019 \\
$\mathrm{X}^{2}$ & -0.0241 & & 1.1874 \\
$\mathrm{Y}^{2}$ & 0.0991 & & -1.8374 \\
\hline $\mathrm{R}^{2}$ & 0.981 & 0.781 & 0.926 \\
Nilai P & 0.0016 & 0.0225 & 0.0194 \\
\hline
\end{tabular}

$\mathrm{X}=$ Persen air yang ditambahkan; $\mathrm{Y}=\mathrm{Suhu}$ barrel $\left({ }^{\circ} \mathrm{C}\right)$

Tabel 4. Hasil optimasi sohun pati ubi Baku Pusus

\begin{tabular}{lccccc}
\hline Target & $\begin{array}{c}\text { Air }(\%) \\
\text { In range }\end{array}$ & $\begin{array}{c}\text { Suhu }\left({ }^{\circ} \mathbf{C}\right) \\
\text { In Range }\end{array}$ & $\begin{array}{c}\text { KPAP }(\%) \\
\text { Minimize }\end{array}$ & $\begin{array}{c}\text { DSA (\%) } \\
\text { In Range }\end{array}$ & $\begin{array}{c}\text { Elongasi (\%) } \\
\text { Target }\end{array}$ \\
\hline Lower & 50 & 90 & 6.1 & 321.63 & 86.3 \\
Upper & 65 & 100 & 10.0 & 557.46 & 262 \\
Importance & +++ & +++ & +++++ & +++ & +++ \\
Solution & 61 & 99 & 6 & 459 & 213 \\
\hline
\end{tabular}

Verifikasi hasil optimasi dilakukan dengan cara membandingkan nilai prediksi dengan nilai aktual. Keberterimaan terhadap persamaan model berdasarkan selang batas bawah (low) dan batas atas (high) dari Confidence Interval $(\mathrm{Cl})$ dan Prediction Interval $(\mathrm{Cl})$ pada selang kepercayaan 95\% (Tabel 5). Hasil verifikasi menunjukkan nilai aktual untuk respon KPAP dan elongasi memiliki kesesuaian dengan nilai prediksi karena nilai respon aktual berada dalam kisaran $\mathrm{Cl}$ dan PI. Nilai aktual respon daya serap air berada di bawah kisaran nilai $\mathrm{Cl}$ dan $\mathrm{PI}$ yang menunjukkan kurang sesuai antara nilai prediksi dan aktual. Dengan demikian, proses optimum dinilai valid untuk memprediksi nilai KPAP dan elongasi sohun, namun kurang valid untuk memprediksi nilai daya serap air. Hal ini bersesuaian dengan persamaan model daya serap air dengan nilai $R^{2}<0.90$ (Tabel 3).

Tabel 5. Nilai prediksi dan aktual KPAP, DSA dan elongasi sohun baku pati Pusus pada kondisi optimum $\left(61 \%\right.$ penambahan air dan suhu barre/ $\left.99^{\circ} \mathrm{C}\right)$

\begin{tabular}{lccccccc}
\hline \multirow{2}{*}{ Respon } & \multicolumn{9}{c}{. } & \multicolumn{2}{c}{$\mathbf{9 5 \%}$ Cl } & \multicolumn{2}{c}{ 95\% PI } \\
\cline { 2 - 8 } & Prediksi & Aktual & SE Mean & Low & High & Low & High \\
\hline KPAP (\%) & 5 & 6,16 & 1 & 4 & 8 & 1.78 & 8.75 \\
DSA (\%) & 462 & 236.95 & 40 & 391 & 533 & 341.54 & 581.57 \\
Elongasi (\%) & 213 & 278,08 & 22 & 155 & 271 & 129.23 & 296.77 \\
\hline
\end{tabular}

\section{Karakteristik sohun tiga varietas ubi Banggai}

Kondisi proses yang dipilih dari hasil optimasi selanjutnya diaplikasikan untuk membuat sohun dari pati Baku Tuu Oloyo dan Baku Boan. Gambar 4a dan 4b secara berturut-turut menyajikan penampakan visual sohun dari ketiga varietas ubi Banggai tersebut dalam bentuk kering dan setelah dimasak selama 6 menit. 
Optimasi Proses Pembuatan Sohun dari Pati Ubi Banggai - Kusnandar, dkk Jurnal Pangan dan Agroindustri Vol.8 No.3: 163-174, Juli 2020

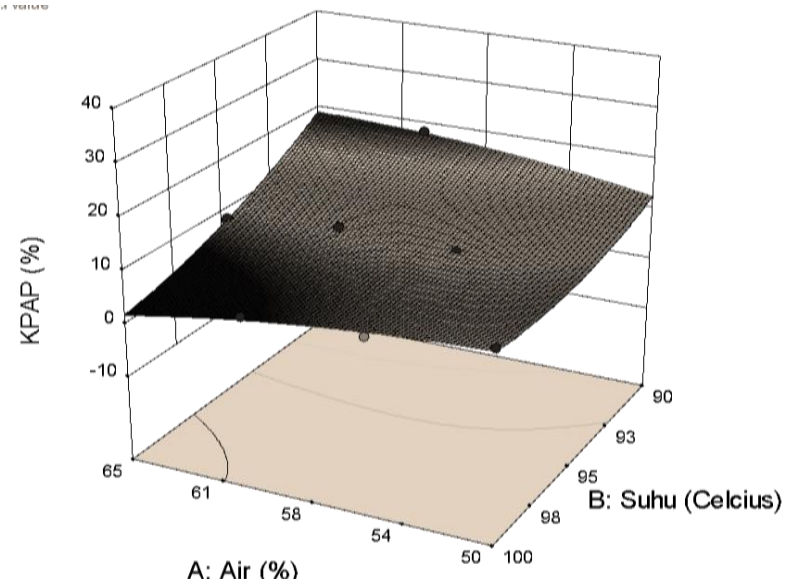

Gambar 1. Model tiga dimensi response surface untuk persen KPAP dari sohun ubi Banggai

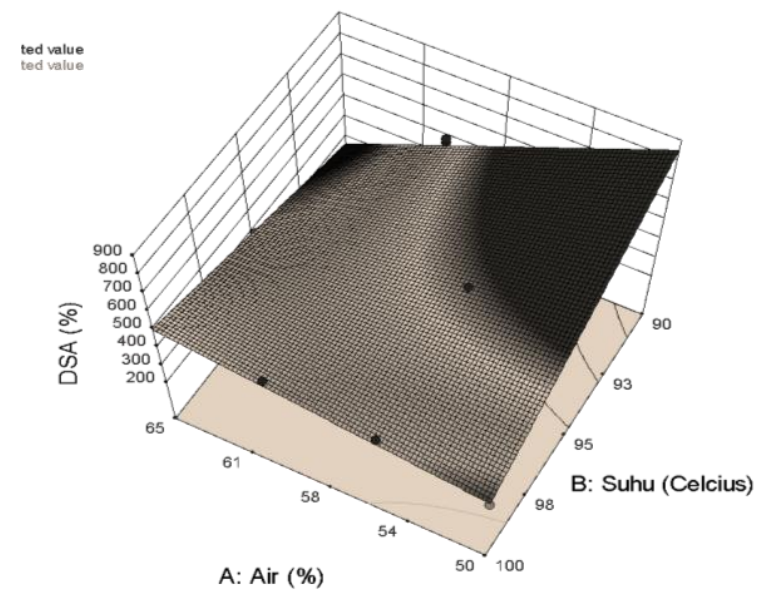

Gambar 2. Model tiga dimensi response surface untuk persen DSA dari sohun ubi Banggai

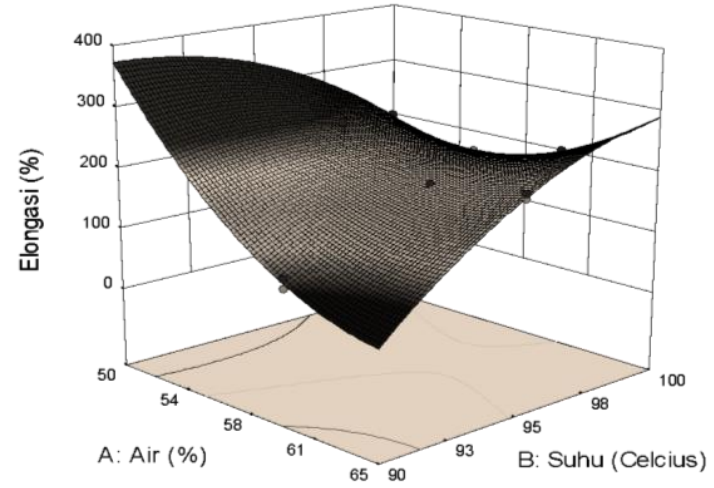

Gambar 3. Model tiga dimensi response surface untuk persen elongasi dari sohun ubi Banggai 


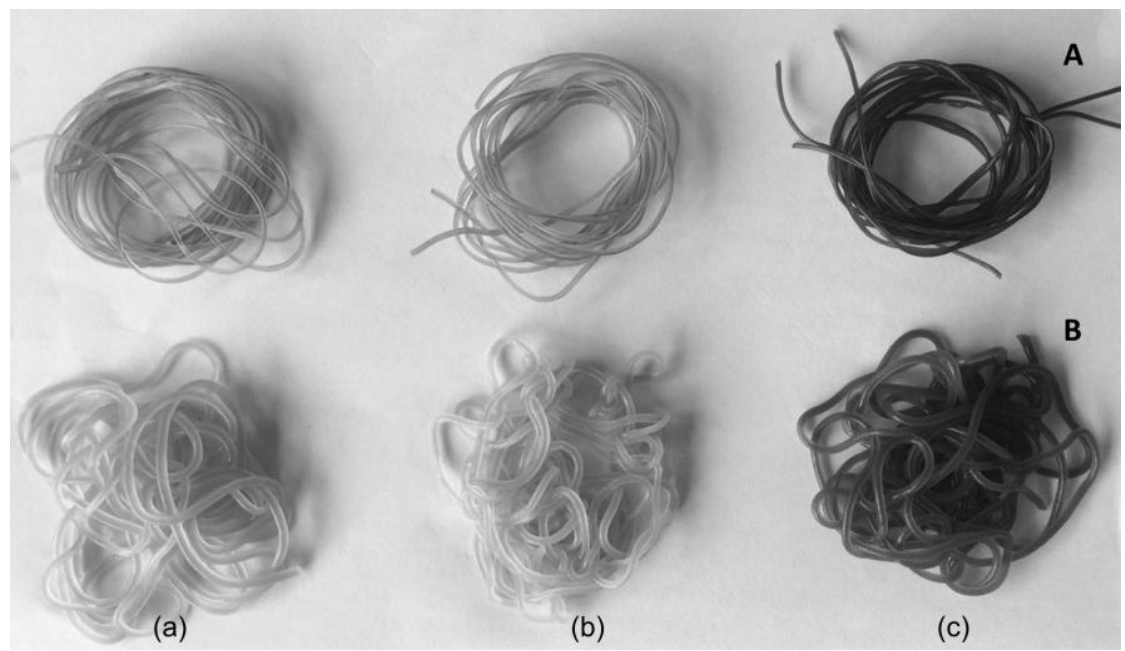

Gambar 4. Sohun pati ubi Banggai kering (A) dan setelah dimasak selama 6 menit (B): (a) Baku Pusus (b) Baku Tuu Oloyo (c) Baku Boan

Warna sohun ubi Banggai memiliki penampakan transluen (terutama baku Pusus dan Baku Tuu Oloyo), dan warna ketiga sohun keabu-abuan dengan intensitasnya berbeda, baik dalam keadaan kering maupun setelah dimasak. Warna sohun ini berbeda dari sohun pati kacang hijau, yang memiliki penampakan transparan dan tidak berwarna. Sohun dari pati Baku Boan memiliki warna yang paling gelap (abu-abu tua), dibandingkan sohun Baku Pusus dan Baku Tuu Oloyo. Warna keabuan sohun dapat disebabkan oleh adanya senyawa fenol yang terbawa ke dalam ekstrak pati. Ubi Banggai mengandung kadar total fenol yang berkisar 30.48$116.90 \mathrm{mg} \mathrm{GAE} / 100 \mathrm{~g}$. Semakin keabuan warna pati, maka kadar fenol semakin tinggi (Amar (2020). Warna visual ini bersesuaian dengan nilai $L$, a dan b, dan satu sama lain menunjukkan perbedaan yang nyata $(p<0.05)$ (Tabel 6). Mutmainah (2020) melaporkan bahwa pati Baku Pusus dan Baku Tu Oloyo memiliki nilai whiteness index (WI) yang tinggi dan browning index (BI) yang rendah, sedangkan pati ubi Baku Boan memiliki nilai WI yang paling rendah dan nilai $\mathrm{BI}$ paling tinggi. Perbedaan warna pati ini juga bersesuaian dengan warna sohun yang dihasilkan.

Tabel 6. Perbedaan karakteristik sohun kering dan matang yang dibuat dari pati Baku Pusus, Baku Tuu Oloyo dan Baku Boan ${ }^{1}$

\begin{tabular}{lccc}
\hline \multirow{2}{*}{ Parameter } & \multicolumn{3}{c}{ Varietas } \\
\cline { 2 - 4 } & Baku Pusus & Baku Tuu Oloyo & Baku Boan \\
\hline Warna sohun kering & $28.90 \pm 0.24^{\mathrm{c}}$ & $24.54 \pm 0.04^{\mathrm{b}}$ & $22.60 \pm 0.01^{\mathrm{a}}$ \\
$\quad$ Nilai L & $0.23 \pm 0.01^{\mathrm{b}}$ & $1.15 \pm 0.01^{\mathrm{c}}$ & $0.07 \pm 0.01^{\mathrm{a}}$ \\
Nilai a & $2.48 \pm 0.04^{\mathrm{b}}$ & $2.70 \pm 0.02^{\mathrm{c}}$ & $1.35 \pm 0.01^{\mathrm{c}}$ \\
$\quad$ Nilai b & & & \\
Warna sohun matang & $30.19 \pm 0.16^{\mathrm{b}}$ & $33.24 \pm 0.14^{\mathrm{c}}$ & $29.43 \pm 0.22^{\mathrm{a}}$ \\
$\quad$ Nilai L & $0.36 \pm 0.22^{\mathrm{a}}$ & $0.51 \pm 0.02^{\mathrm{b}}$ & $1.03 \pm 0.02^{\mathrm{c}}$ \\
Nilai a & $-3.73 \pm 0.76^{\mathrm{b}}$ & $-2.04 \pm 0.07^{\mathrm{a}}$ & $-5.42 \pm 0.04^{\mathrm{c}}$ \\
Nilai b & & & \\
Karakteristik sohun matang & & & \\
$\quad$ KPAP (\%) & $6.16 \pm 0.63^{\mathrm{a}}$ & $7.12 \pm 0.67^{\mathrm{b}}$ & $8.54 \pm 0.90^{\mathrm{b}}$ \\
DSA (\%) & $278.08 \pm 29.26^{\mathrm{a}}$ & $310.94 \pm 37.87^{\mathrm{a}}$ & $320.70 \pm 47.18^{\mathrm{a}}$ \\
Elongasi (\%) & $236.95 \pm 23.40^{\mathrm{a}}$ & $204.05 \pm 14.14^{\mathrm{a}}$ & $201.90 \pm 30.90^{\mathrm{a}}$ \\
\hline
\end{tabular}

${ }^{1}$ Sohun diproses pada kondisi penambahan $61 \%$ air dan suhu barre $/ 99^{\circ} \mathrm{C}$

Nilai pada baris yang sama diikuti huruf yang berbeda menunjukkan perbedaan yang nyata $(p<0.05)$ 
Nilai KPAP ketiga sohun berkisar 6.16-8.54\% (Tabel 6), yang lebih rendah dari yang dipersyaratkan (<10\%) (Collado et al., 2001). KPAP ketiga sohun tersebut berbeda nyata $(p<0.05)$, dengan KPAP sohun pati Baku Pusus yang paling rendah, sedangkan sohun Baku Boan paling tinggi (Tabel 6). Hal ini dapat disebabkan oleh pengaruh kadar amilosa yang tinggi dan ketahanan panas pasta pati yang tinggi dari ketiga pati ubi Banggai (Mutmainah, 2020). Dengan kadar amilosa yang tinggi dalam pati ubi Banggai, maka gel sohun yang terbentuk sangat kuat, sehingga padatan yang hilang ke dalam air pemanas menjadi rendah. Dari ketiga pati ubi Banggai, pati ubi Baku Pusus menunjukkan kekuatan gel yang paling tinggi, sedangkan pati ubi Baku Boan paling rendah (Mutmainah, 2020), yang bersesuaian dengan nilai KPAP yang diperoleh. Karakteristik pemasakan sohun ubi Banggai ini menyerupai sohun pati kacang hijau, yaitu struktur gelnya sangat kompak dan tidak banyak mengalami kehilangan padatan selama dimasak (Li et al, 2011). Persen KPAP sohun pati ubi Banggai lebih rendah dibandingkan sohun ubi jalar (13.06-36.45\%) (Muhandri et al., 2017) dan pati HMT ubi jalar (20.63-36.58\%) (Lase et al. (2013).

Ketiga sohun juga memiliki daya serap air yang cukup tinggi yang tidak berbeda satu sama lain ( $p>0.05)$ (Tabel 6). Walaupun daya serap airnya tinggi, namun tekstur sohun tidak lengket. Hal ini juga terkait dengan kekuatan gel yang tinggi dan profil pasting pati ubi Banggai yang relatif stabil selama fase pemasakan (memiliki viskositas breakdown yang relatif kecil), dan memiliki viskositas setback yang tinggi (Mutmainah, 2020). Amilosa berperan penting dalam pembentukan tekstur sohun karena kemampuannya membentuk ikatan hidrogen yang kuat antara molekul amilosa dengan air setelah proses gelatinisasi, sehingga dapat mengikat air lebih banyak (Whistler et al., 2012).

Ketiga sohun pati ubi Banggai juga memiliki nilai elongasi yang tinggi, yaitu berkisar $201.90-236.95 \%$ (Tabel 6), yang satu sama lain tidak berbeda nyata ( $>0.05)$. Elongasi yang tinggi juga dimiliki oleh sohun dari pati kacang hijau (Wang et al., 2015). Sohun pati ubi Banggai memiliki elongasi yang relatif tinggi dibandingkan dengan sohun pati jagung $(58.18 \%)$ (Interpares et al., 2015), dan sohun ubi jalar (17.45-34.90\%) (Lase et al., 2013). Kandungan amilosa yang tinggi dari pati ubi Banggai menghasilkan untaian sohun yang tidak mudah putus.

Hasil penelitian ini menunjukkan bahwa pati ubi Banggai dari varietas Baku Pusus, Baku Tuu Oloyo dan Baku Boan menghasilkan sohun yang mirip sohun dari pati kacang hijau. Hal ini menjadi keunggulan yang dimiliki oleh pati ubi Banggai yang tidak ditemui pada pati alami dari umbi-umbian lainnya. Tingginya kadar amilosa dan profil pasting yang menyerupai profil pasting dari pati kacang hijau berkontribusi pada kualitas sohun yang dihasilkan.

\section{SIMPULAN}

Sohun ubi Banggai varietas Baku Pusus dapat diproses dengan penambahan $61 \%$ air, $2 \% \mathrm{NaCl}$, suhu barrel ekstruder $99^{\circ} \mathrm{C}$ dan kecepatan ulir $130 \mathrm{rpm}$. Sohun yang dihasilkan memiliki KPAP yang rendah $(<10 \%)$, dan daya serap air dan elongasi yang tinggi. Sohun dari pati Baku Tuu Oloyo dan Boan yang diproses pada kondisi yang sama menunjukkan nilai KPAP yang lebih tinggi dibandingkan sohun pati Baku Pusus, namun nilainya masih di bawah $10 \%$. Daya serap air dan elongasi dari ketiga sohun ini tidak berbeda secara signifikan. Ketiga sohun menunjukkan penampakan transluen dan berwarna keabu-abuan yang berbeda. Intensitas keabuan terutama terlihat pada sohun Baku Boan. Berdasarkan karakteristik pemasakannya (KPAP, DSA dan elongasi), maka ketiga pati ubi Banggai tersebut dapat menjadi alternatif bahan baku untuk pembuatan sohun dengan karakteristik fisik yang mirip sohun pati kacang hijau.

\section{DAFTAR PUSTAKA}

Akinoso R, Olatoye K, Ogunyele O. 2016. Potentials of trifoliate yam (Dioscorea dumetorum) in noodles production. Journal of Food Processing and Engineering. 7:8, 3-6. doi: 10.4172/2157-7110.1000609 
Amar AA. 2020. Karakteristik Tepung Ubi Banggai (Dioscorea sp) dan Aplikasinya pada Beras Analog. Tesis Master. IPB. Bogor.

Bas D, Boyaci IH 2007. Modeling and optimization I: Usability of response surface methodology. Journal of Food Engineering. 78:836-845. doi: https://doi.org/10.1016/ j.jfoodeng.2005.11.024.

Boy R, Soeharsomo. 2013. Tanaman umbi-umbian di Kabupaten Banggai Kepulauan. Dalam Prosiding Seminar Nasional Sumber Daya Genetik Pertanian, Bogor, 151-159.

Budijanto, S., Y.I. Andri, D.N. Faridah, S. Noviasari. 2017. Karakterisasi kimia dan efek hipoglikemik beras analog berbahan dasar jagung, sorgum, dan sagu aren. Agritech. 37:4, 402-409. doi: http://doi.org/10.22146/agritech.10383.

Chen Z, Sagis LMC, Legger A, Linssen JPH, Schols HA, Voragen AGJ. 2002. Evaluation of starch noodles made from three typical Chinese sweet-potato starches. Journal of Food Science. 67:6,3342-3347. doi: 10.1111/j.1365-2621.2002.tb09589.x.

Collado LS, Mabesa LB, Oates CG, Corke H. 2001. Bihon-type noodles from heat-moisturetreated sweet potato starch. Journal of Food Science. 66:4, 604-609. doi:10.1111/j. 1365-2621.2001.tb04608.x.

Hendrawan Y, Susilo B, Putranto AW, Riza DF Al, Maharani DM, Amri MN. 2016. Optimasi dengan alogaritma RSM-CCD pada evaporator vakum waterjet dengan pengendali suhu fuzzy pada pembuatan permen susu. Agritech. 36:2, 226-232. doi:10.22146/ agritech.12868.

Herawati D, Kusnandar F, Sugiyono, Thahir R dan Purwani EY. 2010. Pati sagu termodifikasi HMT (heat moisture-treatment) untuk peningkatan kualitas bihun sagu. Jurnal Pascapanen Pertanian. 7:1,7-15.

Interpares P, Haryadi, Cahyanto MN. 2015. The effect of retrogradation on the physicochemical properties of maize starch noodle and its prebiotic potential. Agritech. 35:2,192-199.

Lase VA, Julianti E, Masniary, LL. 2013. Bihon type noodles from heat moisture treated starch of four varieties of sweet potato. Jurnal Teknologi dan Industri Pangan. 24:1,89-96. doi:10.6066/jtip.2013.24.1.89.

Li W, Shu C, Zhang P, Shen Q. 2011. Properties of starch separated from ten mung bean varieties and seeds processing characteristics. Food Bioprocess Technology. 4:814-821. doi: 10.1007/s11947-010-0421-6.

Muhandri T, Ahza AB, Syarief R, Sutrisno. 2011. Optimasi proses ekstrusi mi jagung dengan metode permukaan respon. Jurnal Teknologi dan Industri Pangan. 22:2, 97-104. doi: https://journal.ipb.ac.id/index.php/jtip/article/view/4239.

Muhandri T, Subarna. 2009. Pengaruh kadar air, $\mathrm{NaCl}$, dan jumlah pasing terhadap karakteristik reologi mi jagung. Jurnal Teknologi dan Industri Pangan. 20:1, 63-70. doi: https://journal.ipb.ac.id/index.php/jtip/article/view/309.

Muhandri T, Subarna, Koswara S, Nurtama B, Ariefianto DI, Fatmala D. 2017. Optimasi pembuatan sohun ubi jalar menggunakan ekstruder pemasak-pencetak. Jurnal Teknologi dan Industri Pangan. 28:1, 36-45. doi: https://doi.org/10.6066/jtip.2017. 28.1.36.

Muhammad K, Kusnandar F, Hashim ZM, Rahman RA, 1999. Application of native and phosphorylated tapioca starches in potato starch noodle. International Journal of Food Science and Technology. 34:3, 275-280. doi: 10.1046/j.1365-2621.1999.00262.x

Mulch RS, Mansur S, Barus HN, Madauna I. 2015. Respon pertumbuhan dan hasil ubi banggai (Dioscorea alata) jenis "Baku Pusus" terhadap pemberian pupuk anorganik, organik dengan mulsa jerami padi. Agroland. 22: 131-137.

Mutmainah M. 2020. Karakterisasi Pati Ubi Banggai (Dioscorea alata) dan Aplikasinya Pada Pembuatan Sohun. Tesis Master. IPB. Bogor.

Nadia L, Wiratakususmah A, Andarwulan N, Hari P, Koaze H, Noda T. 2014. Characterization of physicochemical and functional properties of starch from five yam (Dioscorea Alata) cultivars in Indonesia. International Journal of Chemical Engineering and Applications. 5:6, 489-496. doi: 10.7763/IJCEA.2014.V5.434. 
Oladunmoye OO, Aworh OC., MaziyaDixo B, Erukainure OL., Elemo GN.. 2014, Chemical and functional properties of cassava starch, durum wheat semolina flour, and their blends, Food Science and Nutrition. 2:2, 132- 138.

Prabudi M, Nurtama B, Purnomo EH. 2018. Aplikasi response surface methodology (RSM) dengan historical data pada optimasi proses produksi burger. Jurnal Mutu Pangan. 5:2, 109-115. Doi: https://journal.ipb.ac.id/index.php/jmpi/article/view/26230.

Purnomo P. 2010. Pemanfaatan Dioscorea spp (Dioscoreaceae) oleh masyarakat di Kabupaten Luwuk dan Banggai Sulawesi Tengah. Prosiding Seminar Nasional Biologi. Prespektif Biologi dalam Pengelolaan Sumber Daya Hayati, Yogyakarta: Universitas Gadjah Mada, 55-56.

Purwani EY, Widaningrum, Thahir R, Muslich. 2006. Effect of heat moisture treatment of sago starch on its noodle quality. Indonesian Journal of Agriculture Science. 7:1, 7-14

Rahardjo YP, Dalapati SA. (2016). Diversifikasi Olahan Uwi banggai Menunjang Ketahanan Pangan, 1616-1624.

Ratnawati SE, Ekantari N, Pradipta RW, Paramita BL. 2012. Aplikasi response surface methodology (RSM) pada optimasi ekstraksi kalsium tulang lele. Jurnal perikanan UGM. 20:1, 41-48.

Retnaningtyas DA, Putri WDR. 2014. Karakterisasi sifat fisikokimia pati ubi jalar oranye hasil modifikasi perlakuan stpp (lama perendaman dan konsentrasi). Jurnal Pangan dan Agroindustri. 2:4, 68-77.

Romadhoni M, Harijono. 2015. Karakteristik pasta tepung gembili, pati sagu dan karagenan serta potensinya sebagai bihun. Jurnal Pangan dan Agroindustri. 3:1, 53-60.

Srichuwong S, Sunarti TC, Mishima T, Isono N, Hisamatsu M. 2005. Starches from different botanical sources I: contribution of amylopectin fine structure to thermal properties and enzyme digestibility. Carbohydrate Polymers. 60:4, 529-538. doi: https://doi.org/10. 1016/j.carbpol.2005.03.004.

Tam LM, Corke H, Tan WT, Li J, Collado LS. 2004. Production of bihon-type noodles from maize strach differing in amilose content. Cereal Chemistry. 81:4, 475-480. doi: https://doi.org/10.1094/CCHEM.2004.81.4.475.

Tsakama M, Mwangwela A, Kosamu I. 2013. Effect of heat-moisture treatment (HMT) on cooking quality and sensory properties of starch noodles from eleven sweet potato varieties. International Reseearch Journal of Agricultural Science and Soil Science. 3:7, 256-261. doi: 10.21082/ijas.v7n1.2006.8-14.

Wang D, Fan DC, Ding M, Ge PZ, Zhou CQ. 2015. Characteristics of different types of starch in starch noodles and their effect on eating quality. International Journal of Food Properties. 18:11, 2472-2486. doi: 10.1080/10942912.2014.983606

Wang W, Zhou H, Yang H, Zhao S, Liu Y, Liu R. 2017. Effects of salts on the gelatinization and retrogradation properties of maize starch and waxy maize starch. Food Chemistry. 214:319-327. doi: 10.1016/j.foodchem.2016.07.040.

Whistler RL, BeMiller JN, Paschall EF. 2012. Starch: Chemistry and Technology. Elsevier $3^{\text {rd }}$ Ed.

Xiao HX, Lin QL, Liu GQ, Yu FX. 2012. A comparative study of the characteristics of crosslinked, oxidized and dual-modified rice starches. Molecules. 17: 10946-10957. doi:10.3390/molecules 170910946.

Zhong Y, Zhu H, Liang W, Li X, Liu L, Zhang X, Yue H, Xue J, Liu X, Guo D. 2018. Highamylose starch as a new ingredient to balance nutrition and texture of food. Journal of Cereal Science. 818-14. doil: 10.1016/j.jcs.2018.02.009. 